\title{
The landscape below the Tinglev outwash plain: a reconstruction
}

\author{
RUD FRIBORG
}

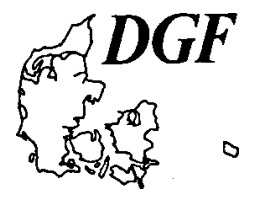

\begin{abstract}
Friborg, R.: The landscape below the Tinglev outwash plain: a reconstruction. Bulletin of the Geological Society of Denmark, Vol. 43, pp. 34-40. Copenhagen 1996-07-14. https://doi.org/10.37570/bgsd-1996-43-04
\end{abstract}

\begin{abstract}
The Tinglev outwash plain is situated in the southernmost part of Jutland, Denmark, and continues southwards across the Danish-German border. Traditionally the melt water deposits between ground surface and the uppermost till are referred to the Weichselian. This paper shows that the melt water sediments can be separated into two outwash plains. The upper one being deposited in the Weichselian, the lower one in the Saalian. To the west the outwash plains are separated by marine Eemian sediments. Further eastwards the units may be distinguished by limnic Eemian deposits as well as Eemian weathering horizons. The paper presents contour maps showing the surface of the uppermost till, a map showing the extension of the marine Eemian in situ, isopach maps of the two outwash plains and a map showing the extension of the Saalian outwash plain.
\end{abstract}

Rud Friborg. Sønderjyllands Amt, Jomfrustien 2, DK-6270 Tønder, Denmark. June 24th, 1996.

\section{Introduction}

The Tinglev outwash plain is situated in southem Jutland and the northernmost part of Germany. The outwash plain was formed in front of the main stationary line of the glaciers in the Weichselian. Nordmann $(1913,1928)$ shows that the marine Eemian in the area around Tønder and at Forballum and Man $\varnothing$ Hølade rests on melt water deposits, which again overlay clayey till. These early works indicate a Saalian outwash plain below the marine Eemian. Sample descriptions by Sigurd Hansen found in the well log database of the Geological Survey of Denmark suggest that he also thought of an outwash plain like this. Friborg $(1988,1989,1990)$ advances the hypothesis of an extensive outwash plain from late Saalian and assumes in 1991 that the plain can be followed from the marsh of Tønder to the former manganese sulphate factory at Vollerup 7 kilometres NNW of Tinglev.

Sørensen (1980) and Penney (1989) deal with the marine Eemian deposits in the Tønder area - primarily near the advanced sea dike - and describe a sequence in which Eemian rests on melt water deposits. The latter are, however, considered to be older than the latest Saale till in this area (the Warthe till). In the present work no instances are quoted in support of the correlation by Sørensen and Penney, since the melt water sand below the Eemian deposits rests on clayey till in all places where till is found. Both Sørensen (1980) and Penney (1989) rely mainly on analyses of the Eemian microfossils, whereas less emphasis has been placed on the correlation of the underlying sediments.

However, melt-water deposits are well-known below the Saale till and in Sjørring \& Frederiksen (1980) they are referred to the Elster on the basis of fine gravel analyses of samples from gravel pits in Møgeltønder.

\section{Saalian till}

Figure 1 shows the surface of the clayey till found below the Tinglev outwash plain. In Figure 1 and in the following figures the Weichselian main stationary line and other ice front positions to the east are shown as jagged lines. The present eastern coastline is not shown. The figures also show areas with high-lying moraine landscape from the Saalian which was not glaciated in the Weichselian or covered by younger melt water sand. These areas are called "Bakkeøer" in Danish (e.g. Toftlund Bakke $\varnothing$ after the town of Toftlund). The term of "Bakkeø" was first used by Enrico H. Dalgas in 1868. He observed how this old landscape projected like islands over the "sea of sand". Since there is no 


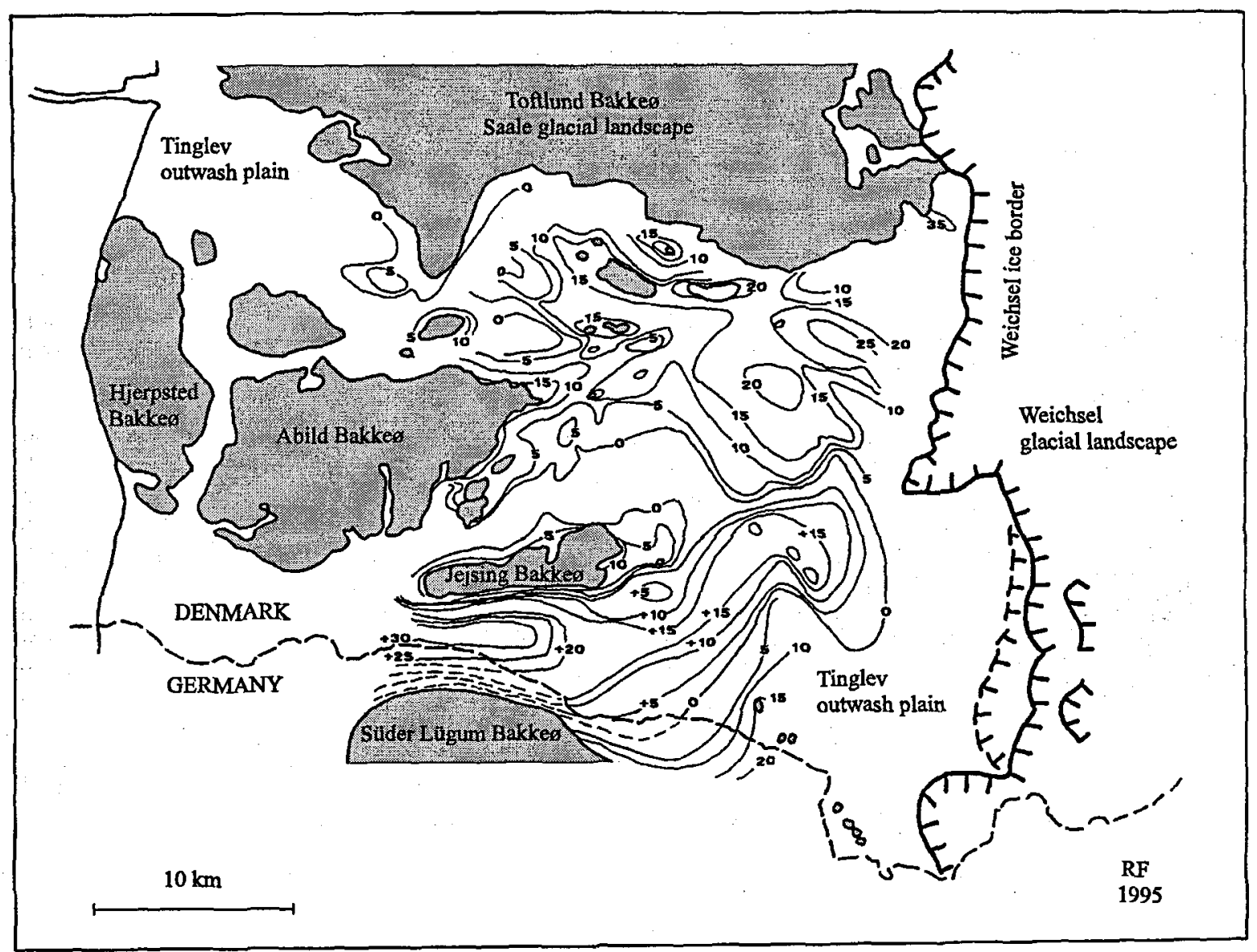

Fig. 1. Contour map showing the level of the till below the Tinglev outwash plain (contours in metres above m.s.1.).

short, adequate English term for this concept, the Danish term is used in text and figures.

The till is assumed to be mainly the so-called Warthe till from the Saalian. It is characteristic in being olive grey, rather sandy and with a considerable chalk content (detrital and as rounded clasts). Furthermore, it is relatively poor in stones and boulders. Pebbles and gravel particles are mostly well rounded. The thickness of the till is typically $10-15$ metres $(+/-15 \mathrm{~m}$ !) and occurrence of a few subordinate, well sorted sand layers is common. This is, inter alia, seen in a well at Vollerup waterworks (DGU No. 159.249). Sjørring \& Frederiksen (1980) carried out fine gravel count on the basis of which they categorized the till at Møgeltønder as Warthe till. The author's field observations during drilling works support the assumption that the Warthe till is widely distributed in the area.

\section{A Saalian outwash plain}

The Saalian outwash plain is often characterized by containing many lignite fragments and much detrital humus. Brown water occurs frequently in the deposit. The colour is caused by dissolved organic matter. The mineral content differs from the Weichselian melt water deposits by showing a far higher content of reworked tertiary quartz grains.

The boundary between melt water deposits from the Saalian and the Weichselian is marked in places by Eemian deposits - marine as well as limnic. Furthermore sudden jumps in the calcium carbonate content of the melt water deposits occur from time to time. At the earlier manganese sulphate factory in Vollerup for example, calcium carbonate leached melt water deposits are found at the top, resting on layers of melt water sand containing calcium carbonate. Below these again calcium carbonate leached melt water deposits are found. This reflects that the upper part of the sediments was $\mathrm{CaCO}_{3}$ leached in postglacial time, whereas the 


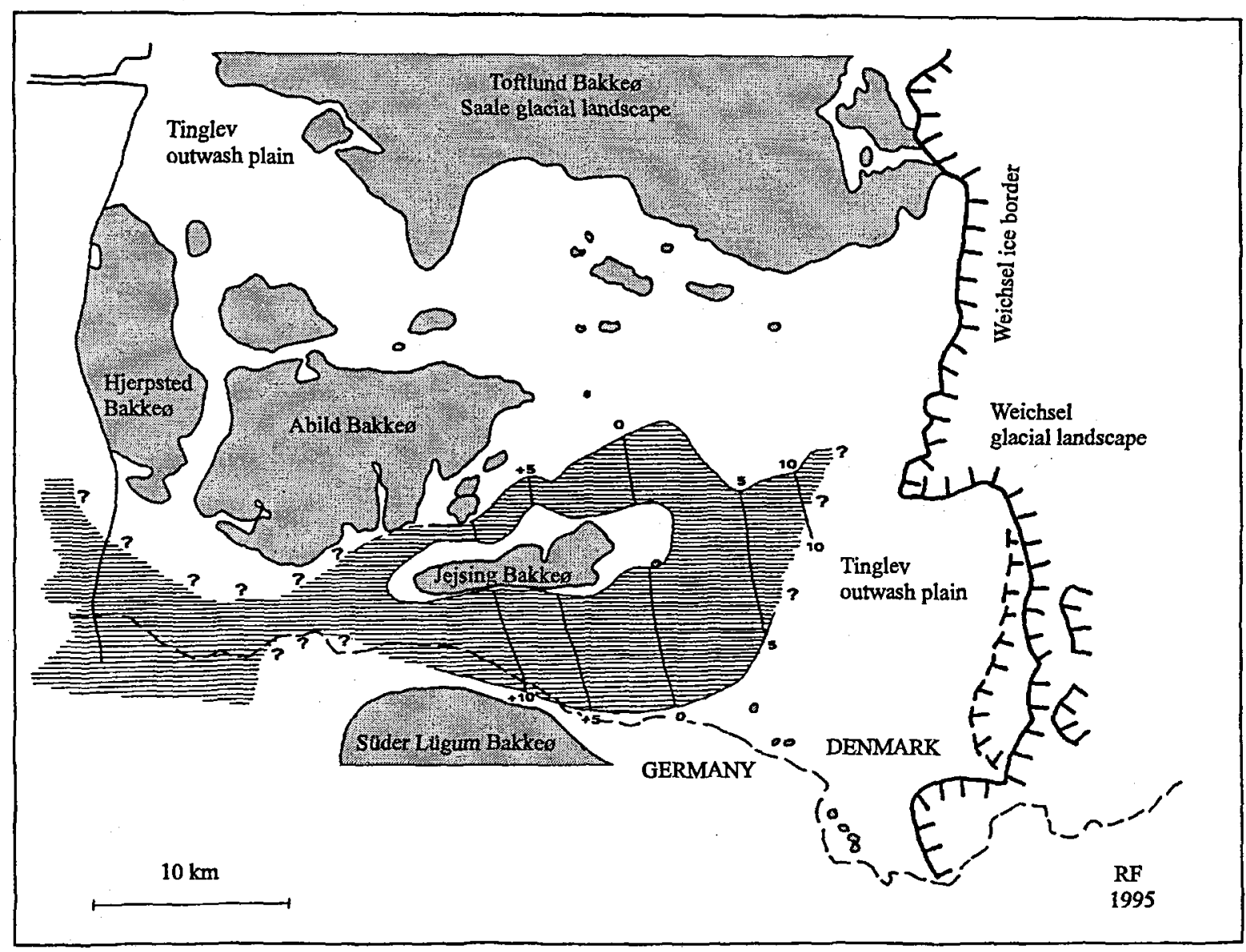

Fig. 2. Extension of the Saalian outwash plain with contour lines for the surface of the plain (metres above m.s.l.).

lower sequence is characterized by weathering in the Eemian. Accordingly a Weichselian outwash plain rests on a Saalian outwash plain.

It is presumed that the top of the limnic Eemian deposits at the boundary between the two outwash plains roughly levels with the top of the lower outwash plain from the Saalian. On the basis of a number of well records showing contents of Eemian deposits, jumps of the $\mathrm{CaCO}_{3}$ content, podsolation horizons and other indications of two outwash plains (lignite fragments, brown water and tertiary quartz grains in the older one) the surface level of the presumed outwash plain has been established.

The base of the Saalian outwash plain is assumed to be present above the Warthe till in the depressions in the moraine landscape. Figure 3 shows the wells used for determining the surface of the Saalian outwash plain. A comparison of Figure 1 with the surface of the assumed top of the Saalian outwash plain allows a delimitation of the extension of the early outwash plain. The result appears in Figure 2 where the contour lines of the surface of the Saalian outwash plain also are shown.

The Saalian outwash plain dips to the WSW with a gradient of about 1 per thousand. This is a little less than the surface of the present outwash plain. However, erosion must have modified the old surface somewhat in the Weichselian. On balance, there is good agreement with the conditions of present outwash plains.

The level of the top of the Saalian outwash plain in the areas where the marine Eemian is found, is mostly uncertain. In the few places where the boundary is certain, there is practically total agreement between the boundary of the marine Eemian and the boundary of the extension of the Saalian outwash plain (see plate III in Nordmann, 1928). Until further, this is assumed as being valid for the whole of the investigated area. The thickness of the early outwash plain can be determined on the basis of Figures 1 and 2 and the result is shown in Figure 4. 


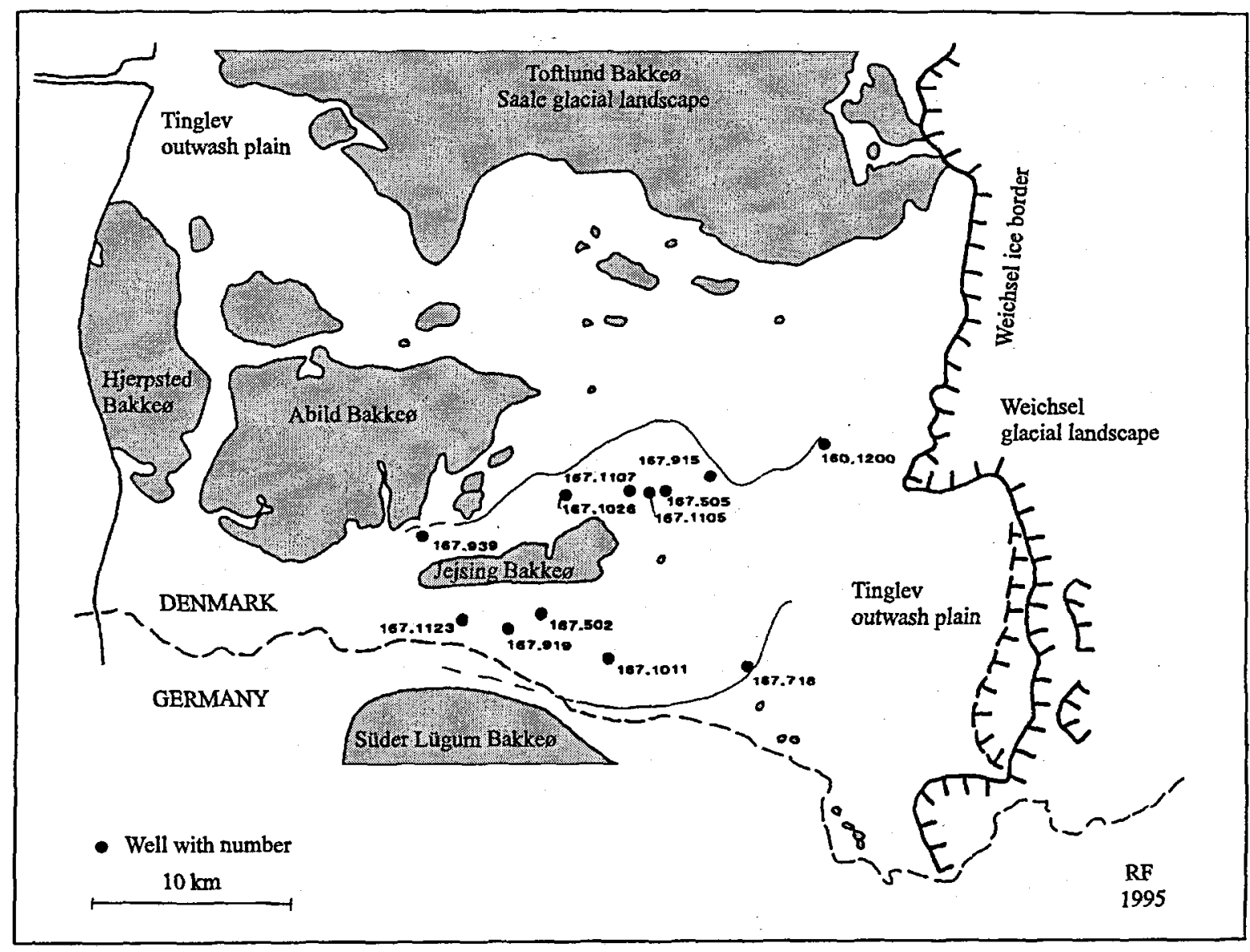

Fig. 3. Location of wells used for the determination of the Saalian outwash plain surface. The numbers refer to well records at the Geological Survey of Denmark.

\section{Marine Eemian}

Figure 5 shows the extension of the marine Eemian. The delimitation in the Tønder area (the southernmost area of occurrence in the figure) is based on Friborg (1990) whereas the delimitation in the marsh of Ballum (northernmost area of occurrence in the figure) is new and based on details from DGU well records. Subsequently, the delimitation of the inlet south of Jejsing Bakke $\varnothing$ has been confirmed by E. Auken and F. Effer$s ø$, who carried out geoelectric investigations in this area for Niels Bøie Christensen (pers. comm.).

\section{Limnic Eemian}

Between Abild Bakkeø and Jejsing Bakkeø presumed limnic Eemian is found in places. The interpretation of these occurrences often rests on drillers' logs (of the type: moor at $17 \mathrm{~m}$ depth). However, a consistent picture of a strike with interglacial freshwater deposits from the boundary of the marine Eemian and about 11 kilometres to the northeast is emerging. Between Süder Lügum Bakke $\varnothing$ in Germany and Jejsing Bakke $\varnothing$ the same situation is found. The occurrence of limnic Eemian indicates that the course of the Eemian stream systems in the area around the Jejsing Bakkeø corresponds completely to today's water courses. 


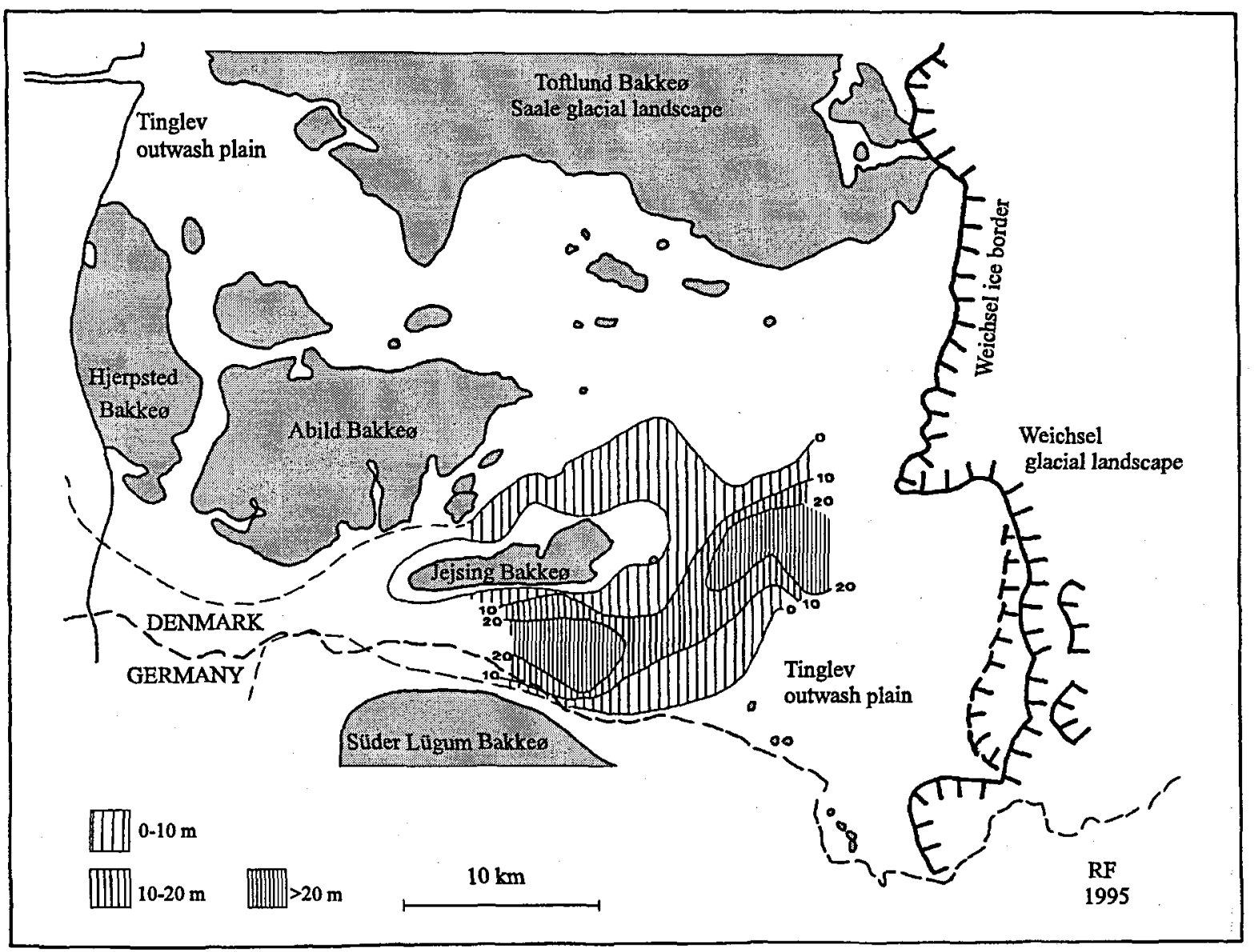

Fig. 4. Isopach map of the Saalian outwash plain (contours in metres)

\section{The Weichselian outwash plain}

Figure 6 shows the thickness of the Tinglev outwash plain sensu stricto, i.e. the melt water sediments from the Weichselian deposited in front of the ice at the main stationary line in the late Weichselian. Within the mapped area the Weichselian outwash plain is about $15 \mathrm{~m}$ thick where it rests on the Saalian outwash plain, while the thickness varies more and is typically smaller where the melt water sand overlays the moraine landscape from the Saalian.

\section{Conclusion}

If further work confirms the model drawn up in this paper, it might be considered to establish the two outwash plains as formal formations. The maps shown do not comprise the entire Tinglev outwash plain since sufficient data (wells) are not yet available. As such data become available the mapped areas will be adjusted and extended.

\section{Acknowledgements}

The author wishes to express his thanks to the County of Sønderjylland for supporting the work on which this article is based. Thanks also to Martha B. Petersen for final drawing of the figures and to Ingrid Clausen for translating the text into English. Finally sincere thanks to Gunnar Larsen. Without his inspiring lectures the author would hardly have devoted his mind to these subjects. 


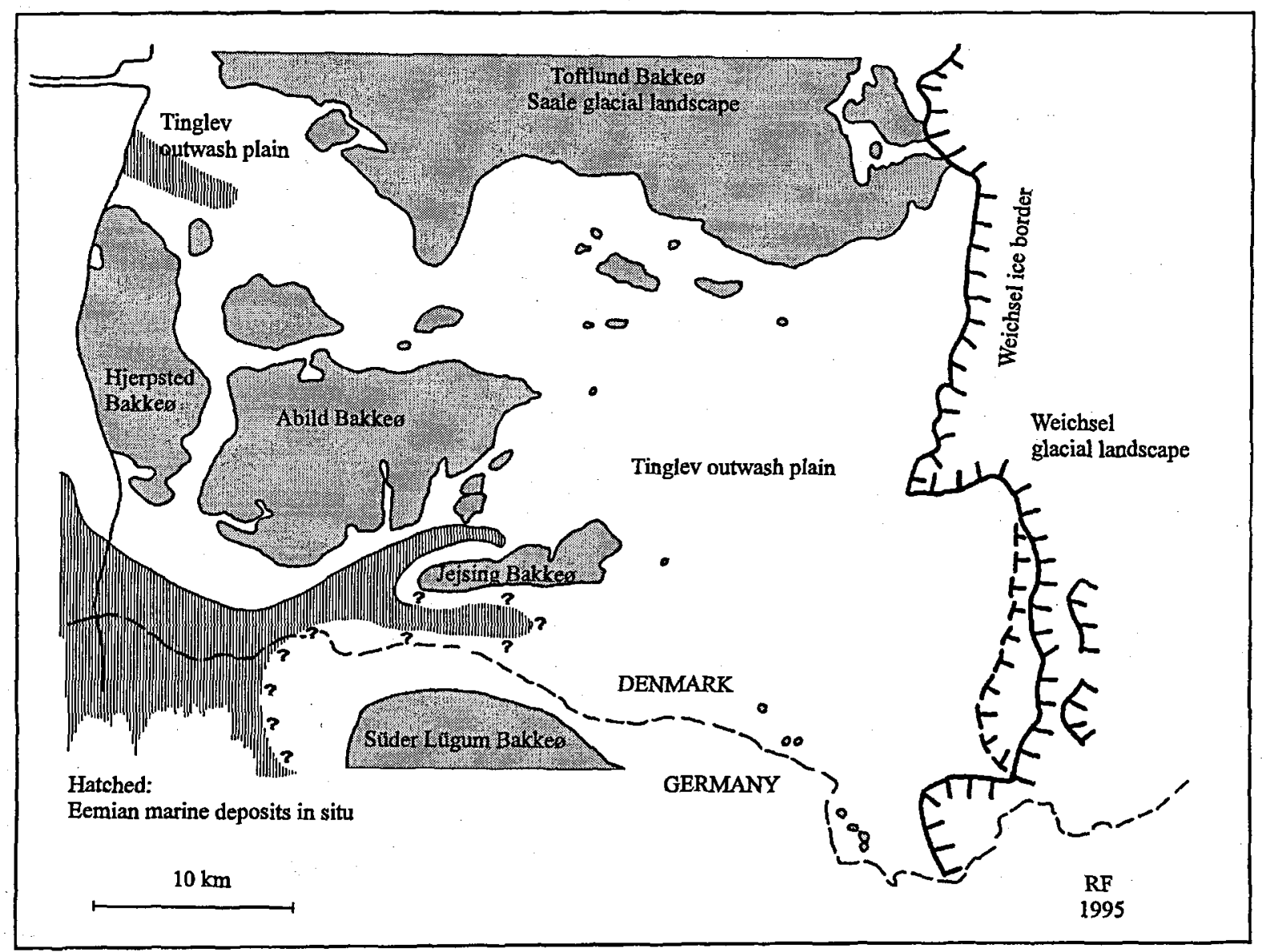

Fig. 5. Extension of the marine Eemian in situ (vertical ruling).

\section{Dansk sammendrag}

Tinglev Hedeslette er beliggende i det sydligste Jylland og strækker sig ind i Nordtyskland. Traditionelt er smeltevandsaflejringerne mellem overfladen og den $\emptyset$ verste moræne blevet henført til Weichsel. Det påvises i denne artikel, at smeltevandsaflejringerne kan inddeles i to enheder; den øvre aflejret i Weichsel og den nedre i Saale. Mod vest adskilles enhederne ved hjælp af marine Eem sedimenter. Mod øst kan enhederne adskilles ved hjælp af Eem ferskvandsafsætninger og forvitringshorisonter af Eem alder. Artiklen prasenterer konturkort, som viser overfladen af den $\emptyset v r e$ moræne, udbredelseskort for marine Eem aflejringer, isopachytkort for de to smeltevandsenheder og et kort, som viser udbredelsen af Saale smeltevandsaflejringen.

\section{References}

Friborg, R. 1988: Nyt om en gammel fjord (Eem). 19. februar 1988. 9 pp. Nyhedsbrev (Sønderjyllands Amt).

Friborg, R. 1989: Geologisk model for Tønder. Maj 1989. 5 pp. Nyhedsbrev (Sønderjyllands Amt).

Friborg, R. 1990: Sidste nyt om en gammel fjord (Eem): 15. november 1990.13 pp. Nyhedsbrev (Sønderjyllands Amt).

Friborg, R. 1991: Geologisk model for mangansulfatfabrikken ved Vollerup, Tinglev hedeslette. 25. april 1991. 31 pp. Intern rapport (Sønderjyllands Amt).

Nordmann, V. 1913: Boringer gennem marint Diluvium i det sydvestlige Jylland og nordvestlige Slesvig. Meddelelser fra Dansk Geologisk Forening, 4, 183-201.

Nordmann, V. 1928: La position stratigraphique des Dépóts d'Eem. Med dansk Sammendrag. Danmarks geologiske Undersøgelse, II. Rk. 47, 1-81.

Penney, D. N. 1989: Microfossils (foraminifera, ostracoda) from an Eemian (last interglacial) Tidal Flat Sequence in south-west Denmark. Quaternary International 3/4, 8591. 


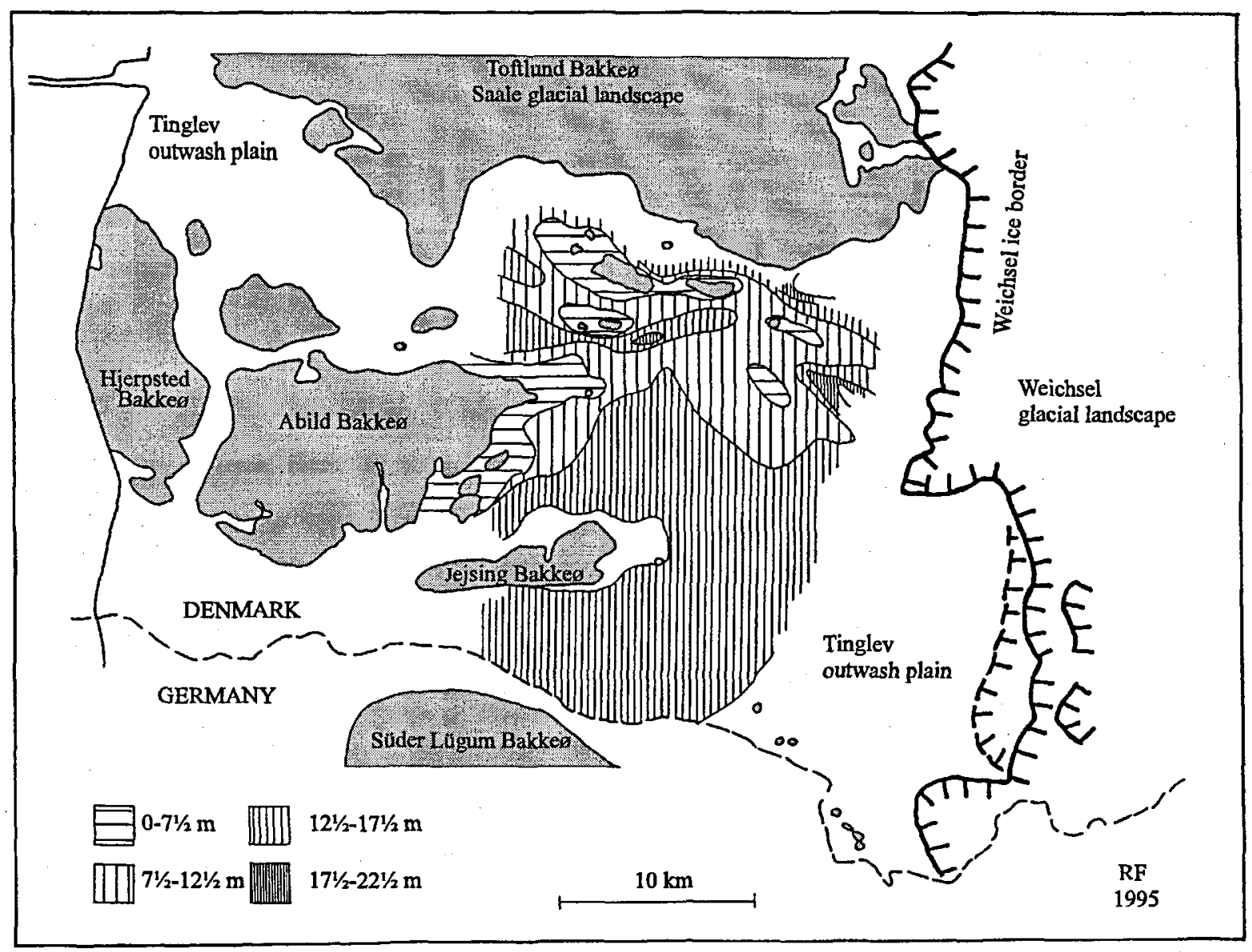

Fig. 6. Isopach map of the Weichselian outwash plain (contours in metres).

Sjørring, S. \& Frederiksen, J. 1980: Glacialstratigrafiske observationer i de vestjyske bakkeøer. Dansk geologisk Forening, Årsskrift for 1979, 63-77.

Sørensen, Aa. B. 1980: Kvartære aflejringers foraminiferer og stratigrafi i Vadehavet vest for Højer. 146 pp. Unpublished Thesis, Geologisk Institut, Aarhus Universitet. 